\title{
Clara de Andrade
}

Atriz, cantora e pesquisadora em teatro. Doutoranda em Artes Cênicas na Universidade Federal do Estado do Rio de Janeiro e mestre em Artes Cênicas pela mesma Universidade. Autora da dissertação: "O exilio de Augusto Boal: reflexões sobre um teatro sem fronteiras" (2O11). Sua pesquisa atual se debruça sobre o teatro politico do teatrólogo brasileiro Augusto Boal. 
"O sertanejo é antes de tudo um forte", escreveu Euclides da Cunha. Parafraseando, eu diria: "O torturador é antes de tudo um covarde."

(BOAL, 2008, p. 54)

\section{RESUMO}

A partir de um estudo de caso sobre o teatrólogo brasileiro Augusto Boal, o presente artigo busca refletir sobre a questão da tortura no teatro de resistência ao regime militar no Brasil. A experiência de tortura vivenciada pelo artista, assim como sua produção enquanto dramaturgo, escritor e diretor teatral, ancoraram profundamente a atual reflexão. Assim, a partir da análise de sua peça Torquemada (1971) e do romance Milagre no Brasil (1979), foi possível perceber suas motivações, suas escolhas estéticas e dramatúrgicas e estabelecer um elo entre o momento de sua vida da experiência de prisão, tortura e exílio e sua produção artística de então.

\section{ABSTRACT}

Starting from a case study on the Brazilian playwright Augusto Boal, this article seeks to reflect on the issue of torture in the theater of resistance to the military regime in Brazil. The experience of torture experienced by the artist, as well as his 
production as a playwright, theater director and writer, deeply anchored the current reflection. Thus, the analysis of his play Torquemada (1971) and the novel Miracle in Brazil (1979) revealed Boal's motivations, his aesthetic and dramaturgical choices and established a link between the moment of his life at the experience of imprisonment, torture and exile, and his artistic production at that moment.

\section{PALAVRAS-CHAVE}

Teatro de Resistência; Augusto Boal; Tortura; Exílio; Ditadura Militar Brasileira.

\section{INTRODUÇÃO}

Dramaturgo, encenador e diretor, incessante pesquisador e teatrólogo - um dos únicos no Brasil que sistematizou suas técnicas e teorias em método teatral Augusto Boal é, certamente, o nosso homem de teatro mais reconhecido internacionalmente. Sua teoria e seu método se estenderam de tal forma pelo mundo que hoje o Teatro do Oprimido de Boal possui praticantes em mais de setenta países. Em 2008, Boal foi indicado ao Nobel da Paz e, em março de 2009, foi nomeado embaixador do teatro pela UNESCO, meses antes de seu falecimento em 2 de maio do mesmo ano.

A história de vida e a carreira de Augusto Boal, assim como sua escrita cênica e dramatúrgica, trazem marcas profundas da luta política do dramaturgo e do 
seu consequente afastamento do Brasil. Na busca incansável de encontrar a forma ideal de realizar um teatro que fosse nacional e ao mesmo tempo libertador, depois de intensa atividade junto ao Teatro de Arena de São Paulo, dirigindo espetáculos que se tornaram símbolos do teatro engajado brasileiro como Arena Conta Zumbi e Opinião (1965), Boal, ainda nos últimos anos do Arena, final dos anos 60 e início dos 70, vai pesquisar as técnicas que irão desembocar, durante o seu exílio, no sistema do Teatro do Oprimido, com suas ideias revolucionárias do Teatro enquanto instrumento de interferência social para o homem comum, através da transformação radical da relação ator-espectador.

Com o golpe militar em $1^{\circ}$ de abril de 1964, todos aqueles que haviam organizado o contato com operários e camponeses foram rapidamente reprimidos e presos: a sede da União Nacional dos Estudantes (UNE) - onde seria inaugurado o teatro do Centro Popular de Cultura (CPC) - é imediatamente atacada, incendiada e os militares encerram o destino do grupo; em Recife, o Movimento de Cultura Popular (MCP) foi fechado logo em seguida ao golpe - Miguel Arraes é um dos primeiros a ser preso e Paulo Freire parte para o exílio ainda em 64. No entanto, aqueles que não travaram contato direto com as massas continuavam ativos na vida cultural e ainda assim unidos na campanha contra o governo recém-instaurado.

Segundo Roberto Schwarz (2008), isso ocorreu porque o governo militar que se instaura imediatamente após o golpe, ao associar-se com o imperialismo, priorizando a integração econômica e militar com os Estados Unidos, não se preocupa em apresentar uma ideologia que o sustente, até mesmo porque, usando da força, dispensa qualquer apoio da população. Neste sentido, nos primeiros anos da ditadura, a arte burguesa manteve-se razoavelmente livre para manifestar seus conteúdos, por mais "engajados" que fossem, contanto que não apresentasse perigo iminente de sublevação da ordem, ou alguma atuação junto às classes populares, como o CPC. Este afrouxamento ideológico dos primeiros anos de censura ajudava a dar um ar de normalidade civil ao regime ditatorial. De acordo com Schwarz (2008), somente em fins de 1968 é oficialmente reconhecida a guerra 
revolucionária no Brasil, respondida pelos militares com policiamento pesado, repressão à imprensa e tortura em proporções absurdas, culminando com a promulgação do Ato Institucional n 5 (Schwarz, 2008, p. 87).

De fato, o Teatro de Arena, apesar da crescente atuação da censura em textos teatrais desde o período dos Seminários de Dramaturgia, só sofreria a repressão radical e definitiva que recaíra sobre o CPC, a partir da realização da I Feira Paulista de Opinião, em 1968, quando os cortes de cerca de 65\% do texto praticamente impediram a realização da mesma. (Boal, 2000, p. 257) Depois de redigido um pedido de liberação para a realização do espetáculo, assinado por Cacilda Becker, que se solidarizou com a situação, a classe artística organizada ficou de vigília no Teatro Ruth Escobar até que a peça pudesse ser apresentada, num estado de Desobediência Civil de abolição à censura. No dia seguinte, com o teatro cercado pela polícia, a classe manteve o estado de Desobediência Civil e avisou aos espectadores que o espetáculo seria apresentado no Teatro Maria Della Costa, onde Fernanda Montenegro estava realizando temporada. A atriz permitiu que seu espetáculo fosse interrompido para que os atores da Feira cantassem as canções que haviam sido proibidas. Segundo Boal, no terceiro dia previsto para apresentação, os teatros de São Paulo se encontravam cercados pela polícia. 0 elenco, acompanhado de espectadores, segue então para a cidade de Santo André e apresenta no Teatro de Alumínio o texto integral da Feira Paulista de Opinião. (Boal, 2000, p. 257)

A promulgação do Ato Institucional $n^{\circ} 5$ e o consequente acirramento da censura e da repressão, portanto, dificultaram muito a sobrevivência do Teatro de Arena em territórios brasileiros. Em 14 de dezembro de 1968, dia seguinte à divulgação do Al-5, Augusto Boal parte para Cuba. (Boal, 2000, p. 264) Depois de um mês, inicia longa turnê com Arena Conta Zumbi pelo México, Peru e Estados Unidos, a convite de Joanne Pottlitzer, onde o espetáculo obteve elogiosas críticas no New York Times. Foi a "internacionalização do Arena" (Boal, 2000, p. 267), um processo necessário, protetor em certo sentido - a solidariedade internacional 
poderia ser útil nos casos de repressão e de fato foi - e um dos primeiros sinais do exílio que já se aproximava. No entanto, o grupo decide voltar para o Brasil e continuar resistindo. (Boal, 2000, p. 270) Em 1970, o Teatro de Arena encena $A$ Resistível Ascensão de Arturo Ui, de Bertolt Brecht, e ensaia novo espetáculo histórico, Arena Conta Bolívar.

Certa noite, em 2 de fevereiro de 1971, caminhando de volta para casa depois do ensaio, na cidade de São Paulo, Augusto Boal vê três homens armados saltarem de um carro. Não teve escolha: foi sequestrado e preso. Boal permanece um mês em cela solitária no DOPS de São Paulo (Departamento de Ordem Política e Social) sob tortura e interrogatórios sistemáticos, comandados por um dos nomes mais temidos da repressão, o temido delegado Sérgio Paranhos Fleury (Boal, 2000, p. 276). Nas palavras de Boal: "É difícil enfrentar com cenários, tanques, com figurinos, fuzis. Perdemos." (Boal, 2000, p. 270)

De início, se passaram sete dias sem que a família e os amigos de Boal tivessem notícia de seu paradeiro. Seu irmão, que por sua vez era do serviço militar, decide ir à delegacia do DOPS, mas o nome de Boal não estava na lista dos presos: sua entrada havia sido feita com o nome de Francisco de Souza, para que ele não fosse encontrado. Ao ouvir um investigador perguntar: "E agora, o que se faz com o corpo?!", o irmão de Boal, em um ato de desespero, sacou sua arma e obrigou que Ihe mostrassem Augusto, como estivesse, vivo ou morto. Os policiais finalmente trazem Boal e os irmãos têm um encontro de cerca de três minutos. Seu sequestro, então, pôde ser oficializado como prisão. (Boal, 2000, 279-280)

Graças à determinação de seu irmão, depois de um mês preso, Boal consegue que seu paradeiro seja noticiado nos jornais. É quando a solidariedade internacional intervém com uma série de protestos contra sua prisão. Desde uma carta redigida por Arthur Miller e assinada por importantes personalidades do teatro mundial como Peter Brook, Richard Schechner, Bernard Dort, Jean-Louis Barrault, Arianne Mnouchkine e Antoine Vitez, a manifestações lideradas por Jack Lang então diretor do Festival de Nancy e que depois veio a se tornar ministro da Cultura 
na França - e telegramas, um deles, de Jean Paul-Sartre, chegou a ser lido em sua sessão solene, e outros vindos até do Japão. Tal pressão acelerou muito o seu processo jurídico e em um mês Boal estava sendo ouvido em julgamento, junto de mais seis pessoas, fato raro naqueles tempos obscuros. Porém, as informações contidas nos depoimentos, mesmo realizados diante do juiz, foram registradas dubiamente, de tal modo que o teatrólogo acabou sendo sentenciado a mais dois meses de prisão preventiva, no presídio Tiradentes. (Boal, 2000, p. 280)

Em outra etapa de seu julgamento, Boal consegue liberação para viajar para a França e se juntar ao Arena, que participava do Festival Mundial de Teatro de Nancy com Zumbi e outras peças-curtas de Teatro-Jornal. Sua presença no Festival contribuiria para uma imagem menos sórdida da ditadura brasileira. Prestes a embarcar, o artista precisou assinar um documento prometendo que voltaria ao país para seu julgamento final. Nesta ocasião, ouviu a seguinte frase do funcionário que Ihe fez assinar a promessa de retorno: "Não prendemos ninguém segunda vez: matamos! Não volte nunca. Nesta linha: assine! Prometa voltar." (Boal, 2000, p. 282). Boal relata ter sido este o único conselho da ditadura que seguiu à risca: partiu definitivamente para o exílio.

\section{NOS PORÕES DE TORQUEMADA}

O primeiro pouso do exílio de Augusto Boal será na Argentina. Além de ser a terra natal de sua mulher, a atriz e psicanalista Cecilia Thumin Boal, a ditadura se mostrava mais branda aos argentinos naquele momento, com o governo militar de transição de Alejandro Lanusse. A fuga para a Argentina, por se tratar de um país 
da América Latina, próximo ao Brasil, significava também a esperança de que se poderia voltar em breve, a ilusão de que a ditadura brasileira logo se extinguiria.

Em Buenos Aires, Boal pôde dirigir sua peça Torquemada, escrita quando ainda se encontrava preso ilegalmente no Brasil. O dramaturgo começou a idealizála em fevereiro de 1971 quando esteve em regime de solitária no DOPS-SP (F1 Fundão). Através de desenhos que eram entregues à sua mãe em dia de visita alegando que eram apenas desenhos para o seu filho Fabian - Boal registrava as cenas que via na prisão. (Abellan, 1998, p. 185) Continuou a escrever a peça no presídio Tiradentes (Pavilhão 1, cela 3, de nome Mario Alves), onde, em cela compartilhada com outros presos políticos, possuía mais "liberdade". Boal enfim consegue finalizar Torquemada em 2 de novembro de 1971, já exilado em Buenos Aires. (Boal, 1973, p. 62) Escrita, portanto, em formato semelhante ao de um diário de prisão - Boal a define como "Relatório" (Boal, 1973, p.61) -, a peça trata explicitamente da questão da tortura e da censura em regimes ditatoriais.

No texto de apresentação da peça, Boal não menciona onde exatamente se passa a ação, mas deixa claro para o leitor, no decorrer das cenas, que pode se tratar tanto de um país da América Latina, quanto de qualquer outro onde já se tenha instaurado um governo autoritário. A figura do inquisidor espanhol Torquemada - conhecido por sua crueldade, estímulo a delações, torturas e assassinatos em público, durante o reino de Aragão e Castela, de 1478 a 1494, com o intuito de alcançar a sangre limpia ao manter na Espanha somente aqueles que teriam sangue "puramente" cristão - aparece como uma alegoria do sistema corrupto e doentio que se instaura no continente latino-americano. O personagem de Dramaturgo, que é preso, interrogado e submetido a toda sorte de torturas, nos remete imediatamente à figura do próprio autor, Boal. Ao final do Prólogo da peça, o ator que representa este papel, como uma quebra de distanciamento brechtiano, se dirige à plateia: "Esta peça foi escrita na prisão Tiradentes, do Estado de São Paulo, Brasil no ano de 1971. Foi escrita também na Espanha, no fim da Idade Média. 
Continua sendo escrita no Chile, depois de tantos anos, no Uruguai, em [E] Salvador. Começa sempre assim.” (Boal, 1990, p. 112)

Na peça de Boal, Padre Tomás de Torquemada é nomeado inquisidor-mor pelo Rei, com o objetivo de pacificar o povo que, segundo ele, quis mais do que podia ao desejar participar do progresso econômico a que o reino vinha assistindo. O Rei pede ajuda a Torquemada para fazer com que o povo "aceite ser escravo". O padre prontamente aceita sua incumbência, e a alusão ao crescimento econômico que se via ocorrer no período do golpe militar brasileiro, assim como em outros países latino-americanos, fica ainda mais nítida: "Meu rei: eu farei um Milagre. Vamos nos enriquecer cada vez mais, e o povo não vai reclamar. (...) Minha primeira providência é esta: que se prenda todo o povo. Quero interrogá-lo." (Boal, 1990, p.112) O "Milagre Brasileiro", sob o preço da tirania, da manutenção da desigualdade e da pobreza, das diversas formas de sujeição e opressão, enfim, da escravidão social e política de um povo.

Primeiramente, no dito prólogo, o texto denuncia os interrogatórios e sessões de torturas vividas pelo personagem nomeado Dramaturgo. Depois, nas cenas que se seguem, mostra-se: a violência que passou a se impor aos estudantes e jovens, por mera suspeita de "subversão", como na cena intitulada Interrogatório em que a personagem Moça é morta em tortura diante de outros Presos; a rotina dos presos políticos e os diferentes segmentos e visões dentro da própria esquerda; a participação da Igreja, os que apoiaram o sistema, e os que defenderam os direitos humanos dos guerrilheiros; o retrato da alta burguesia no personagem Paulo, sua relação de promiscuidade e dependência com o capital internacional, e assim mesmo sua derrota. Todas essas doenças sociais sob o comando cruel do inquisidor-mor, El Torquemada.

O autor dedica a peça à amiga Heleny Guariba que, depois de ministrar oficina junto com Cecilia Thumin no Arena, vinha trabalhando como assistente de Boal, até ser detida. Será na prisão do DOPS, e depois no presídio Tiradentes, que os dois irão se reencontrar. Heleny já estava em presídio há cerca de um ano e 
havia sido chamada à delegacia política para acareação com prisioneiros recentes. É quando reconhece a voz de Augusto na cela ao lado e lhe dá conselhos para que não confessasse absolutamente nada, nem um pequeno detalhe, mesmo que inconsequente, e que tivesse um comportamento mais "brechtiano" que "stanislavskiano" durante seu tempo na prisão. Segundo Boal, assim eram os conselhos de Heleny: "Aqui a gente não pode só sentir, tem que tentar compreender. Tem que ter muito efeito de distanciamento... Nada de emoções..." (Boal, 1979, p. 21). "Trata de ver as coisas brechtianamente. Eles nunca têm nenhuma prova contra ninguém: o que eles têm são só confissões!" (Boal, 1979, p.27) Heleny logo é mandada de volta ao presídio e, meses depois, é brutalmente assassinada pelos militares. Até hoje Heleny Guariba é considerada como "desaparecida". ${ }^{1}$ Boal lhe dedica a peça com as palavras: "Para Heleny, assassinada nas prisões de Torquemada." (Boal, 1973, p. 61)

Desde a sua dedicatória, portanto, o texto de Torquemada, carrega o choque da experiência de prisão e tortura vivida pelo seu autor, Augusto Boal. O pensador Walter Benjamin (1975) no ensaio "Sobre alguns temas de Baudelaire" traz ricas reflexões sobre a relação dos choques traumáticos e o artista da modernidade. $\mathrm{Na}$ primeira parte de seu ensaio, Benjamin se refere ao trabalho de Freud "Além do Princípio do Prazer", que propõe uma correlação entre a memória e a consciência, a partir da hipótese de que "a consciência surja no lugar da marca mnemônica" (Benjamin, 1975, p. 44), donde então surgiria a ameaça dos choques traumáticos. A descrição feita por Benjamin da experiência do choque é, enfim, uma das primeiras

\footnotetext{
1 Heleny também o aconselha a não se impressionar quando ele visse a amiga em comum Albertina - que tinha sido a primeira mulher de Boal - sair da cela sem conseguir andar, depois de ser torturada: se tratava de mero "fingimento" para que não a torturassem mais. Boal soube mais tarde que Heleny estava, claro, tentando protegê-lo, que a amiga Albertina de fato quase não podia mais andar depois das sessões de tortura, mas para ele, aquelas palavras o ajudaram a ter mais coragem. (BOAL, 1979, p. 21-22) Em sua autobiografia, Boal diz que os torturados, então, ao imitarem com perfeição as dores que sentiam estavam desta vez sendo "stanislavskianos" e lembra Fernando Pessoa: "O poeta é um fingidor, / finge tão completamente, / que chega a fingir que é dor, / a dor que deveras sente." (BOAL, 2000, p. 276)
} 
e mais fortes imagens do indivíduo moderno, fragmentado, incapaz de reagir aos estímulos com que se depara.

Benjamin também se refere a Freud no que diz respeito ao funcionamento frustrado da reflexão que produziria o "espanto". Para ilustrar esta passagem, cita uma imagem na qual este elemento foi cruamente fixado pelo poeta Baudelaire: um duelo de esgrima no qual o artista, antes de sucumbir, grita de espanto, como metáfora do processo de criação. E é sobre esta possível relação entre processo de criação artística e memória do trauma que nos deteremos agora mais atentamente.

No caso de Augusto Boal, as experiências de tortura e do exílio parecem ser mais fortes do que ele próprio e, a partir desse momento, passam a se impor em sua criação artística, tanto no que diz respeito à dramaturgia quanto esteticamente, nas escolhas e métodos, como diretor.

Torquemada mostra claramente a luta psicológica de Boal com o trauma recém-vivido. Ele relata que escrevera e dirigira o texto por não acreditar no que havia Ihe acontecido na prisão, precisava ver tudo aquilo acontecer fora dele, em cena, para que pudesse, assim, enxergar a si mesmo. "Dirigi Torquemada. Não acreditava no que me havia acontecido. Precisava vê-lo acontecer fora de mim, em cena, para que me pudesse ver, separar-me de mim. Eu e a palavra, eu e o ator. Só assim me entenderia." (Boal, 2000, p. 294) Nesta fala de Boal transparece nitidamente o deslocamento, que ele via ser necessário, da figura de seu próprio eu encarnada no texto, nas palavras e nas situações dramáticas encontradas na peça, como reflexo das cenas vividas e assistidas na prisão. E ainda, como um desejo de reencontrar sua própria identidade:

"Não me bastava espelho nem memória: precisava me ver em alguém que me roubasse o nome, o Augusto Boal que eu pensava ser, que trazia colado ao rosto, às mãos, ao peito. Já não sabia quem era eu ou tinha sido. Queria ouvir palavras que pronunciei na tortura. Voz empostada de ator bem treinado reproduzindo gritos 
roucos. Ver-me longe de mim. Dirigir-me como dirijo atores". (Boal, 2000, p. 294)

Toda a dor que ele mesmo não pôde conter será catalisada para a escrita e exposta em cena como um grito de socorro e de desespero, no esforço de assimilação e compreensão do trauma vivido, de modo a se realizar uma verdadeira catarse dentro dele mesmo. Na rubrica inicial do texto, Boal ainda esclarece: "Tudo nesta peça é verdadeiro: ocorreu realmente. A única ficção é a estrutura da própria peça, que busca a teatralidade." (Boal, 1990, p. 102)

Torquemada se inicia então com uma longa rubrica que descreve como o autor vê seus personagens em cena. O espaço cênico: uma cela com cinco camas duplas e uma porta com uma grade alta; os figurinos: "os atores se vestem iguais, mas não de uniforme, já que se trata de presos políticos" (Boal, 1973, p.63), "os policiais se vestem de policiais ou de frades. Deve existir uma mistura de roupas históricas e modernas." (Boal, 1990, p. 102) E sobre o estilo de representação, o autor afirma ser "basicamente realista", porém diz que cada cena em particular deve ser feita segundo o estilo que melhor lhe convenha, sem necessidade de se manter uma forma de representação única para todo o espetáculo.

A primeira edição do texto, argentina (1973), traz informações sobre um estilo de encenação (não-realista) que se aproximam muito do sistema coringa, informações estas que não se encontram na edição brasileira (1990). Na primeira, Boal observa que os atores devem intercalar seus personagens em cada cena e que nenhum personagem deve ser representado por um mesmo ator em duas cenas consecutivas. "Cada personagem deve ter sua "máscara de comportamento" (movimentos, voz, etc.) que deve ser mantida por todos os atores que o representem." (Boal, 1973, p. 64) Porém, em relação à estrutura dramática propriamente dita ocorre o contrário, a estrutura do sistema coringa é mantida mais fielmente na segunda versão, a brasileira. As cenas denominadas de Explicação, por exemplo, na edição em português têm como porta-voz o Ator - exatamente como na estrutura do coringa, na qual se acrescenta apenas a denominação do Ator 
como Coringa - enquanto que na edição argentina, estas mesmas cenas, ainda que sob o título de Explicación, aparecem apenas como rubrica. (1990, p.144)

Em seguida à rubrica de abertura da peça, se segue outra que descreve o ambiente do Prólogo: uma sala de torturas. Cinco policiais vestidos de frades já se encontram em cena (Barba, Atleta, Baixinho, Frade 1, Frade 2) e preparam os aparelhos a serem utilizados: um pedaço de pau, duas pequenas mesas, uma garrafa de água com sal, um aparelho elétrico, espécie de reostato (dispositivo que possibilita aumentar ou diminuir a corrente elétrica de um circuito), cordas, algemas. Barba é o chefe das operações. Ele traz cadernos e papéis em uma pasta, que examina. Entram mais um frade e o Dramaturgo. A cena se inicia com um breve interrogatório e rapidamente o Dramaturgo é ordenado a tirar a roupa e a sentar-se no chão. Barba e Atleta o colocam em posição fetal no pau-de-arara. ${ }^{2}$ Desde esse primeiro momento já é possível reconhecer a experiência vivida por Boal, projetada em sua escrita. Um trecho da cena mostra claramente esta transposição:

BARBA - Onde é que você conheceu o Aluísio, aqui ou em Paris?

DRAMATURGO - Em nenhum lugar.

BAIXINHO - Lá em Paris, na casa do Aluísio, quem é que se reunia com vocês? (...) Aluísio é nome de guerra ou é nome verdadeiro?

DRAMATURGO - Não sei.

BARBA - Não é que ele não saiba: ele não se lembra. Dá um pouquinho de memória aí pra ele. (Novo choque elétrico. Novo grito.)

\footnotetext{
2 "Pau-de-arara: (...) Aplicado já nos tempos da escravidão para castigar escravos "rebeldes", consiste em amarrar punhos e pés do torturado já despido, e sentado no chão, forçando-o a dobrar os joelhos e a envolvê-los com os braços; em seguida passar uma barra de ferro de lado a lado perpendicularmente ao eixo longitudinal do corpo - por um estreito vão formado entre os joelhos fletidos e as dobras do cotovelo. A barra é suspensa e apoiada em dois cavaletes (no DOPS de São Paulo, os cavaletes são substituídos por duas escrivaninhas), ficando o preso dependurado. (...)" (BAFFA, 1989, p. 66-67)
} 
BAIXINHO - A gente tem provas de que você se encontrava com o Aluísio em Paris.

DRAMATURGO - Eu encontrei muita gente em Paris, mas não lembro o nome de todo mundo.

BARBA - Está melhor: você se encontrou com o Aluísio, mas quando você entregou os recados, você ainda não sabia como era o nome dele, não é verdade? (...)

DRAMATURGO - Não, eu não disse isso. Eu não levei nenhum recado pra ninguém. Mas pode ser que eu tenha me encontrado com uma pessoa chamada Aluísio, ou Pedro, ou Paulo, ou José, por casualidade. Foi isso que eu disse. Mas não levei recado nenhum a ninguém.

BAIXINHO - Recado não, mas artigos você levou. Recados, você trouxe, tá lembrando agora? (...) (Choque e grito.)

DRAMATURGO - Não é verdade nem uma coisa nem outra.

BAIXINHO - Então como é que foram publicados tantos artigos difamando o nosso país?

DRAMATURGO - Eu não li nada.

BAIXINHO - Mas os artigos foram publicados! Sim ou não? (Para o Atleta) Pergunta! (Choque e grito) $\mathrm{Na}$ revista Temps Modernes. Sim ou não? (...) Vai ter que confessar!

DRAMATURO - Confessar o quê?

BARBA - Confessa que você difama o nosso país quando viaja para o exterior.

DRAMATURGO - No exterior eu apresento os meus espetáculos, as minhas peças. Isso não é difamar.

BARBA - Você difama e tchau. Confessa de uma vez.

DRAMATURGO - Mas como? Como é que eu difamo? 
BARBA - Você difama, porque, quando você vai ao exterior, você diz que no nosso país existe tortura. (Há um silêncio. $O$ Dramaturgo, pendurado no pau-de-arara, não consegue evitar um sorriso.)

BAIXINHO - Ele está rindo.

DRAMATURGO - (Tentando parar o riso.) Não, não, eu não estou rindo, quer dizer, eu só ri um pouquinho, quer dizer, como você disse que eu difamava porque aqui não existe tortura... bom, quer dizer, o que é que eu tou fazendo aqui? Isso daqui o que é que é?... Isso é tortura!

BARBA - Manda brasa pra que ele aprenda! (O Atleta vai fazer o jogo normal de ligar o aparelho e desligar imediatamente.) Deixa, deixa um pouco mais de tempo pra que ele aprenda. (O Dramaturgo grita continuamente de dor pelo choque elétrico demorado. Depois de uns instantes, o Atleta desliga.)

BARBA - Claro que isso é tortura. Mas você tem que reconhecer que eu estou te torturando com todo o respeito! Não estou te dando porrada na cara nem apagando o cigarro aceso na tua boca. Estou fazendo o mínimo indispensável. (...)

BAIXINHO - (Olhando o Dramaturgo) Parece que ele tá mal.

(BOAL, 1990, p. 104-106)

Depois de Torquemada, Boal escreve o romance Milagre no Brasil, no qual relata em primeira pessoa a sua experiência na prisão. Publicado inicialmente em Portugal em 1976, e no Brasil somente em 1979, sua narrativa funciona quase como um depoimento e nos remete imediatamente à denúncia presente em Torquemada. No trecho abaixo ele descreve a sensação do choque elétrico em seu corpo, pendurado no pau-de-arara:

- Então vamos começar. Você já vai ver que sabe muito mais do que pensa que sabe. Vai lembrar muito mais do que pensa que lembra. Por exemplo: quem é o Eduardo? 
- Não sei...

Creio que nem terminei de falar e soltei um grito fortíssimo. Nunca me havia ouvido gritar semelhante grito. Nem pude acreditar que era a minha voz. Em geral, quando uma pessoa quer gritar, prepara o grito. Esse foi o primeiro grito da minha vida sem nenhuma preparação. Por isso era diferente, não parecia meu, não se parecia a nenhum grito conhecido. Comecei a tremer convulsivamente: sentia a eletricidade em toda parte do meu corpo, nos braços, nas pernas, na cabeça, no estômago. Minhas orelhas pareciam queimar. O choque elétrico não tinha durado muito - talvez alguns poucos segundos - mas os seus efeitos continuavam muito além. Eu respirava fortemente, muito tenso. Ouvia perguntas sem identificar quem perguntava (...). Quando minha cabeça dava volta eu conseguia ver o relógio do baixinho, mas não via as horas. Que horas seriam? Eu queria saber as horas. Talvez isso pudesse me distrair da dor. (Boal, 1979, 62-63)

A narrativa prossegue com a descrição exata da cena transcrita anteriormente de Torquemada. A sensação reflexa do choque, porém, é cada vez mais forte:

O barbado, muito sério, ordenou:

- Deixa, deixa, um pouco mais. Outra vez. E mais. Que se foda! Chora! Chora! Você sabe chorar? Riu, não é, agora vai ter que chorar!

Desta vez não me lembro nem mais ou menos quanto durou o choque, mas certamente foi muito mais do que eu podia aguentar, em estado de consciência. Eu me lembro que o meu corpo saltava pendurado pelos joelhos, como se fosse uma máquina de quebrar pedras. Lembro do meu grito continuado e das caras ferozes, ofendidas. Deve ter passado muito tempo. Desmaiei. Não sei se uma ou duas vezes, se muito ou se pouco tempo. Só sei que depois 
de algum tempo eu ainda continuava ali, pendurado (...). (Boal, 1979, p.67)

“Tortura e Sintoma Social”, da psicanalista Maria Rita Kehl (2010), apresenta uma profunda reflexão sobre a questão da tortura e sua inserção nos discursos coletivos de poder e memória social. Maria Rita nos aponta para a face hedionda, porém inegavelmente humana da tortura: além de se inscrever justo no laço social, não se conhece outro ser, a não ser o próprio ser humano, capaz de instrumentalizar seu semelhante, e ainda ter prazer com isso, a pretexto de se obter uma suposta "verdade". No que toca à questão do corpo torturado, a autora esclarece ser este "um corpo roubado ao seu próprio controle; corpo dissociado de um sujeito, transformado em objeto nas mãos poderosas do outro - seja o Estado ou o criminoso comum". (Kehl, 2010, p. 130-131) Segundo Kehl (2010), ao instaurar a separação entre corpo e sujeito, a tortura remontaria, portanto, ao dualismo "corpo/mente, ou corpo/espírito", fazendo do corpo sob tortura simples carne sem alma à mercê da crueldade e do "gozo do outro". (Kehl, 2010, p.131)

Será nessa mesma direção que o escritor Jaime Ginzburg em seu artigo "Escritas da Tortura" (2010) chama a atenção para o estudo dos psicanalistas Maren e Marcelo Viñar, do livro Exílio e Tortura (1992), que apresenta relatos de pacientes torturados no Uruguai e reflexões sobre as dificuldades específicas encontradas por estes pacientes. A partir dos estudos de caso, os autores chegam à conclusão que o objetivo da tortura é exatamente "provocar a explosão das estruturas arcaicas constitutivas do sujeito, isto é, destruir a articulação primária entre o corpo e a linguagem." Tamanha desproporção de posições de poder entre torturador e torturado levaria o sujeito, em situações extremas de sofrimento corporal e psíquico, a identificar-se com o inimigo à sua frente, na tentativa de resgate da realidade e de sua constituição enquanto sujeito, passando assim, em muitos casos, a identificar-se, também, com o pensamento do torturador. (Ginzburg, 2010, p. 142) 
De acordo com Maria Rita Kehl, esta identificação ocorreria porque a fala que pertence ao sujeito deixa de lhe pertencer, já que o torturador, tendo o poder físico e psicológico sobre sua vítima, pode arrancar dela a palavra que "ele quer ouvir", e não a que o sujeito teria a dizer. Nas palavras da psicanalista:

"Resta ao sujeito preso ao corpo que sofre nas mãos do outro o silêncio, como última forma do domínio de si, até o limite da morte. E resta o grito involuntário, o urro de dor que o senso comum chama de "animalesco". Por que animalesco se é um homem que urra?" (Kehl, 2010, p. 131).

É a própria Maria Rita Kehl quem nos responde: o grito não seria mais a expressão do sujeito assim como não o é, tampouco, a palavra extorquida. E, talvez, ao evocar o terror, convém chamá-lo de animalesco justamente para não se correr o risco de se identificar com ele. (Kehl, 2010, p.131)

O grito involuntário e a palavra extorquida são, portanto, a manifestação possível do trauma no momento em que é vivido. E nos levam ao problema de como lidar com a memória deste trauma, que muitas vezes precisa de outras linguagens que não a verbal para se manifestar, e assim ser passível de elaboração.

Michael Pollak, em seu texto "Memória, Esquecimento, Silêncio" (1989), se refere justamente ao trabalho psicológico do indivíduo de assumir o controle sobre suas próprias feridas e lembranças pessoais. $O$ autor reflete também sobre o papel do cinema nos processos de "enquadramento da memória" ${ }^{3}$, o que nos leva a fazer uma breve reflexão sobre a possível função do teatro nestes mesmos processos. $O$ pesquisador argumenta que a importância crescente do cinema na formação e

3 Tentativa de inserção das memórias coletivas dentro de limites e referências no tempo e no espaço que as definem como pertencentes a diferentes grupos sociais. Por exemplo, um evento que tenha sido vivido por um grupo de amigos de uma geração específica sobre o qual apenas eles podem se lembrar. Pollak cita também o termo "memória enquadrada" de Henry Rousso. (POLLAK, 1989, p. 2) 
reorganização das memórias se dá pelo fato de ele se dirigir à emoção e não apenas ao pensamento cognitivo. O teatro, assim como o cinema, lida com 0 pensamento cognitivo e também com a emoção. Seu instrumento, no entanto, não é a câmera, mas sim a presença física do corpo do ator diante do público. Nas mais diferentes formas e expressões do teatro ao longo da história, o corpo humano será instrumento para o ator, seja para acessar suas próprias memórias e emoções ao longo de seu processo de criação, seja na comunicação com o espectador, ao expressar-se em cena com diferentes matizes de voz, gesto e movimento.

A relação do teatro com a memória, portanto, estará intimamente ligada a um discurso do corpo tanto no sentido de uma memória corporal quanto no sentido da encenação de lembranças de fatos passados. Através de uma espécie de "corporificação" da memória, o teatro possibilitará então que "memórias subterrâneas" (Pollak, 1989, p. 2) venham à tona. Este caráter de denúncia e reflexão faz do teatro um poderoso instrumento para a reestruturação da memória de processos históricos marcados pelo trauma e pelo silêncio.

Este é, portanto, um traço que aparece claramente em Torquemada. Ao expor cenas da tortura de maneira tão crua, como no trecho que transcrevemos anteriormente, a peça atua como denúncia aos crimes de tortura cometidos durante o regime militar no Brasil e em toda a América Latina. A análise dos depoimentos de Augusto Boal sobre seu processo de escrita e do próprio texto da peça nos mostram a necessidade do dramaturgo e diretor do "retorno" da "palavra extorquida" pela tortura, apontada por Maria Rita Kehl, da exposição em cena do "grito involuntário, o urro de dor", dele próprio enquanto sujeito, como de todos aqueles que também foram torturados. Assim, o texto de Torquemada pode ser visto como uma tentativa de reestruturação da memória política do trauma, individual e social, da ditadura militar brasileira. Outras peças deste mesmo período como Patética (1977) de João Ribeiro Chaves Netto, Fábrica de Chocolate (1979) de Mário Prata, ambas inspiradas no assassinato do jornalista Vladimir Herzog pelos militares, e Campeões do Mundo (1979) de Dias Gomes, que narra as diferentes motivações de jovens 
engajados na luta armada, acabaram por exercer também este papel de denúncia, atuando como expressões de um teatro de resistência à ditadura militar.

Boal se remete à mesma cena que transcrevemos anteriormente da tortura, ainda uma vez mais, porém anos mais tarde, em sua autobiografia. (Boal, 2000, p. 279) Em entrevista a Joan Abellan (1998), no ano em que se propunha a escrever suas memórias, Boal relata a permanência física e psicológica destas lembranças:

Tem coisas que a gente não esquece nunca, que são para sempre. Inclusive coisas físicas. Meus joelhos, por exemplo. Continuam sem funcionar muito bem por conta da tortura. E também mentalmente. (...) agora que já se passaram tantos anos - (...) quase trinta anos, já - com a distância, com o tempo que passou, mesmo assim me vêm muitas imagens. E elas vêm com muita, muita força. Existem coisas que não se apagam. (Abellan, 1998, p. 184)

O corpo físico e psíquico de Boal, portanto, foi profundamente marcado pela tortura, prisão e exílio, definindo-se então como um "lugar de memória", ${ }^{4}$ histórica, política e, principalmente, humana.

\section{REFERÊNCIAS}

ABELLAN, Joan. Boal Cuenta Boal. Barcelona: Institut del Teatro, 2001.

ANDRADE, Clara de. O exílio de Augusto Boal: reflexões sobre um teatro sem fronteiras. Rio de Janeiro: Dissertação de mestrado. Programa de Pós-Graduação em Artes Cênicas, Centro de Letras e Artes, Universidade Federal do Estado do Rio de Janeiro (UNIRIO), 2011.

$4 \quad$ Expressão citada por Maria Paula Araújo e Myrian Sepúlveda acerca da memória inscrita nos corpos de indígenas que participaram da guerra civil no Peru. In: ARAÚJO \& SEPÚLVEDA, 2007, p. 108. 
ARAÚJO, Maria Paula; SEPÚLVEDA, Myrian. História, memória e esquecimento: Implicações políticas. REVISTA CRÍTICA DE CIÊNCIAS SOCIAIS, Coimbra, n. 79, p. 95-111, 2007.

ARNS. D. Paulo Evaristo. Brasil nunca mais: Um relato para a história. Petrópolis: Vozes, 1985.

BAFFA, Ayrton. Nos porões do SNI: retrato do monstro de cabeça oca. Rio de Janeiro: Objetiva, 1989.

BENJAMIN, Walter. Sobre alguns temas de Baudelaire. A modernidade e os modernos. Rio de Janeiro: Tempo Brasileiro 1975.

BOAL, Augusto. Torquemada. Buenos Aires: Ediciones Noé, 1973.

BOAL, Augusto. Teatro do Oprimido e Outras Poéticas Políticas. $2^{\circ}$ ed. Rio de Janeiro: Civilização Brasileira, 1977.

BOAL, Augusto. Milagre no Brasil, Rio de Janeiro: Civilização Brasileira, 1979, 291 p.

BOAL, Augusto. Teatro de Augusto Boal - Volume 2: Histórias de nuestra América, A Lua pequena e a caminhada perigosa, Torquemada. Coleção Teatro 18 - Direção de Adalgisa Pereira da Silva e Fernando Peixoto. São Paulo: Hucitec, 1990.

BOAL, Augusto. Hamlet e o Filho do Padeiro: Memórias Imaginadas. Rio de Janeiro: Record, 2000.

COSTA, Iná Camargo. A hora do teatro épico no Brasil. Rio de Janeiro: Paz e Terra, 1996.

FERRAROTTI, Franco. Histoire et Histoires de Vie: la méthod biographic dans les sciences sociales. Tradução para o francês de Marianne Modak. Prefácio de 
Georges Balandier, introdução de Emmanuel Lazega. Paris: Libraire des Meridiens, 1983.

GINZBURG, Jaime. Escritas da tortura. In: TELES, Edson \& SAFATLE, Vladimir (orgs.). O que resta da ditadura: a exceção brasileira. SP: Boitempo, 2010; p.133149.

KEHL, Maria Rita. Tortura e Sintoma Social. In: TELES, Edson \& SAFATLE, Vladimir (orgs.). O que resta da ditadura: a exceção brasileira. São Paulo: Boitempo, 2010; p. 123-132.

POLLAK, Michael. Memória, Esquecimento, Silêncio. ESTUDOS HISTÓRICOS, n. 3, Rio de Janeiro: 1989, p.3-15.

SCHWARZ, Roberto. "Cultura e política, 1964-1969 - Alguns esquemas. In: O pai de família e outros estudos. São Paulo: Companhia das Letras, 2008, p. 70-111.

TELES, Edson \& SAFATLE, Vladimir (orgs.). O que resta da ditadura: a exceção brasileira. SP: Boitempo, 2010.

VIÑAR, Maren \& VIÑAR, Marcelo. Exílio e Tortura. São Paulo: Escuta, 1992. 